\title{
SEASONAL VARIABILITY OF SELECTED NUTRIENTS IN THE WATERS OF LAKES NIEPRUSZEWSKIE, PAMIATKOWSKIE AND STRYKOWSKIE
}

\author{
Anna Zbierska' ${ }^{1}$, Czesław Przybyła ${ }^{1}$, Żaneta Dwornikowska $^{1}$ \\ 1 Institute of Land Reclamation, Environmental Management and Geodesy, Poznan University of Life Sciences, \\ Piątkowska 94E, 60-649 Poznań, Poland, e-mail: anzbier@up.poznan.pl, przybyla@up.poznan.pl
}

Received: 2016.06 .29

Accepted: 2016.07.30

Published: 2016.09.20

\begin{abstract}
The paper presents the evaluation of seasonal and long-term changes in selected nutrients of three lakes of the Poznan Lakeland. The lakes were selected due to the high risk of pollution from agricultural and residential areas. Water samples were taken in 6 control points in the spring, summer and autumn, from 2004 to 2014. Trophic status of the lakes was evaluated based on the concentration of nutrients (nitrates, nitrites, ammonium, nitrogen and phosphorus) and indicators of eutrophication. Studies have shown that the concentration of nutrients varied greatly both in individual years and seasons of the analyzed decades, especially in Lakes Niepruszewskie and Pamiątkowskie. The main problem is the high concentration of nitrates. In general, it showed an upward trend until 2013, especially in the spring. This may indicate that actions restricting runoff pollution from agricultural sources have not been fully effective. On the other hand, a marked downward trend in the concentrations of $\mathrm{NH}_{4}$ over the years from 2004 to 2014, especially after 2007, indicates a gradual improvement of wastewater management. Moreover, seasonal variation in $\mathrm{NH}_{4}$ concentrations differed from those of $\mathrm{NO}_{3}$ and $\mathrm{NO}_{2}$. The highest values were reported in the autumn season, the lowest in the summer. Concentrations of nutrients and eutrophication indexes reached high values in all analysed lakes, indicating a eutrophic or hypertrophic state of the lakes. The high value of the N:P ratio indicates that the lakes had a huge surplus of nitrogen, and phosphorus is a productivity limiting factor.
\end{abstract}

Keywords: accumulation of nutrients, lake eutrophication, nitrates (V), water pollution, trophic state

\section{INTRODUCTION}

Issues of water quantity and quality have become increasingly important in recent years. The OECD report ${ }^{1}$ shows that the demand for drinking water in the world will increase by $55 \%$ by the year 2050 and during that time more than $40 \%$ of the world population may be affected by water shortages. According to the UNESCO report [2014] the current problem is not only the quantity of water, but most of all its quality. The report indicates that $24 \%$ of mammals and $12 \%$ birds, which natural habitats are inland waters, are threatened with extinction. Furthermore, if surface waters (especially lakes and rivers) are of poor quality, they are less suitable sources of water for municipal water supply, industry, fisheries and recreation [Kajak 2001, Przybyła et al. 2014]. The use of too high doses of fertilizers natural and artificial, and disordered wastewater managment is particularly disadvantageous for lakes due to storage significant amounts of nutrients flowing from the catchment area [Bechmann 2005, Cherry et al. 2008, Zbierska et al. 2002, Ławniczak et al. 2008]. The aim of the study was to determine the evaluation of seasonal and long-term changes in selected nutrients of three lakes of the Poznan Lakeland in the years between 2004-2014.

\footnotetext{
${ }^{1}$ OECD Environmental Outlook to 2050: The Consequences of Inaction.
} 


\section{MATERIAL AND METHODS}

Seasonal variation of nutrient concentrations in the waters of the three lakes located in the Poznań Lakeland mesoregion (315.51) was determined based on monitoring data collected by the Institute of Land Reclamation, Environmental Management and Geodesy, Poznań University of Life Sciences. Water for physicochemical analyses was sampled in 2004-2014, three or four times a year: in spring (April / May), summer (June / July) and autumn (September / October). In total, samples were collected at six monitoring points (pp-k), from a depth of 0.5 to $1.0 \mathrm{~m}$, in locations of the old shore water intakes for long range irrigation sprinklers. The distribution of these points was related with the continuity of analyses initiated in 1999.

Water samples from Lake Niepruszewskie were collected in two locations (Niepruszewo and Zborowo), while from Lake Strykowskie in three points (Jeziorki, Sapowice and Strykowo). The results were averaged. Data for Lake Pamiątkowskie were recorded at a single monitoring point (Pamiątkowo). This gave from 34 to 102 measurement series in the analyzed decade. The results of selected physicochemical indicators (dissolved oxygen, total nitrogen and total phosphorus) were referred to the limit values defined in the Regulation of the Minister of Environment of 22 October 2014 [Journal of Laws 2014 item 1482] on the classification of the status of surface waters.

The trophic status of the lake was evaluated based on the concentration of nutrients (nitrogen and phosphorus), referring them to the limit values for eutrophication of surface waters specified in the Regulation of the Minister of Environment of 23 December 2002 and other criteria used for the classification of eutrophication of surface waters such as the N:P ratio [Nurnberg 2001, Vollenweider and Kerekes 1982].

\section{CHARACTERISTICS OF THE LAKES}

All the analyzed lakes are located in the water divide of the Warta river and the Oder basin. A comparison of basic morphometric parameters for studied lakes are given in Table 1. Water abiotic type $3 \mathrm{~b}$ means that they are lakes with high calcium contents, considerable outflow from the catchment, non-stratified, with a coefficient of Schindler $>2$. They are characterized by high susceptibility to degradation (category 3 ), which is determined by small depth and the ratio of the bottom active surface to the volume of epilimnion and a significant basin elongation. They are ribbon lakes with a longitudinal axis, close to the north - south direction. Fed mainly by the flowing rivers and small, seasonally dry, drainage ditches of adjacent fields and meadows, which have a pronounced effect on fertilization of waters.

The smallest among the analyzed reservoirs is Lake Pamiątkowskie, located about $10 \mathrm{~km}$ southeast of Szamotuly. Arable land (UR) accounts for about $83 \%$ of the area, while forests less than $8 \%$ [Przybyła et al. 2011]. The northern shore of the lake is occupied by buildings of the village Pamiątkowo with a bathing beach and camping site on the eastern shore.

Lake Niepruszewskie is located on the border between the communes of Buk and Dopiewo. The water level in the lake is regulated by a weir located at the outlet of the Samica Stęszewska river from this reservoir, which is why the area and depth of lake are variable and depend on the level of damming [Murat-Błażejewska et al. 2008, Zbierska et al. 2002]. The immediate catchment of the lake is agricultural in character ( $82 \%$ UR), with numerous residential and recreational buildings located in the close proximity to the lake, in villages of Niepruszewo, Zborowo and Cieśle [Przybyła et al. 2011, Zbierska and Lawniczak 2002]. The lake is used for recreation and fishing. On the south of the lake there is the Poznan-

Table 1. Characteristics of morphometric parameters in the studied lakes

\begin{tabular}{|l|c|c|c|c|c|c|c|c|c|c|c|}
\hline Parameter & Area & Volume & $\begin{array}{c}\text { Mean } \\
\text { depth }\end{array}$ & $\begin{array}{c}\text { Max. } \\
\text { depth }\end{array}$ & $\begin{array}{c}\text { Max. } \\
\text { lenght }\end{array}$ & $\begin{array}{c}\text { Max. } \\
\text { width }\end{array}$ & $\begin{array}{c}\text { Bank } \\
\text { line } \\
\text { length }\end{array}$ & $\begin{array}{c}\text { Bank line } \\
\text { development }\end{array}$ & $\begin{array}{c}\text { Exposure } \\
\text { index }\end{array}$ & $\begin{array}{c}\text { Status } \\
\text { acc. to } \\
\text { WIOŚ }\end{array}$ & $\begin{array}{c}\text { Susceptibility } \\
\text { to poluttion }\end{array}$ \\
\hline \multicolumn{1}{|c|}{ Lake } & ha & thous. $\mathrm{m}^{3}$ & $\mathrm{~m}$ & $\mathrm{~m}$ & $\mathrm{~m}$ & $\mathrm{~m}$ & $\mathrm{~m}$ & - & - & - & - \\
\hline Niepruszewskie & 242.3 & 7578.3 & 3.1 & 5.2 & 4900 & 700 & 11100 & 2.01 & 78.2 & $\mathrm{non}\left({ }^{*}\right)$ & $\mathrm{III}$ \\
\hline Pamiątkowskie & 76.1 & 1680.8 & 2.2 & 4.9 & 2540 & 565 & 5750 & 1.86 & 34.6 & $\mathrm{III} /\left(^{* *}\right)$ & \\
\hline Strykowskie & 305.3 & 13637.4 & 4.5 & 7.7 & 8440 & 720 & 19550 & 3.16 & 67.8 & $\mathrm{III}^{* * *}$ & $\mathrm{III}$ \\
\hline
\end{tabular}

Sources: Choiński [2006], Jańczak [1996], The Regional Inspectorate of Environmental Protection in Poznań (WIOŚ) Raport from 2004* (non-classified), 2009** and 2006***. 
Berlin motorway A2, and also there are disused bog lime mine pits [Przybyla et al. 2011]. The main anthropopressure force at the lake is agriculture, thus in the years 2004-2012 the lake and the Samica Stęszewska river supplying it have been designated as sensitive to water pollution by nitrates from agricultural sources (OSN area) in accordance with the requirements of the Nitrates Directive [Directive 1991]. After the next cycle of verification in 2012, the boundaries of OSN areas were changed, excluding the lake and the river.

Lake Strykowskie is the largest among the analyzed reservoirs, and also one of the largest lakes in the Poznan Lakeland (Table 1). It is highly elongated, running from the northeast to the southwest. It is fed mainly by the inflow from Dobierzyn and minor drainage ditches of the immediate catchment of the lake [Czarnecka 2005]. Water in the lake is dammed to supply agricultural irrigation systems. The total catchment of the lake is typically agricultural $(90.5 \%$ of the area) with sparse residential development in the villages of Januszewice, Słupia, Sapowice and Strykowo. Forests cover only $6.5 \%$ and are found only in the north-west. The lake is also considerably burdened with recreation [Przybyla et al. 2011].

\section{RESULTS AND DISCUSSION}

The study showed considerable differences in the concentrations of nutrients and indicators of eutrophication during the last decade (Table 2).

Oxygen conditions in the studied lakes were generally good. The average annual value exceeded $7 \mathrm{mg} \mathrm{O}_{2} \cdot \mathrm{dm}^{-3}$, while the minimum values were generally higher than $4.5 \mathrm{mg} \mathrm{O} \cdot \mathrm{dm}^{-3}$. Only in the summer of 2005 for one station of Lake Niepruszewskie a decline in oxygen concentration to a level of $2.0 \mathrm{mg} \mathrm{O}_{2} \cdot \mathrm{dm}^{-3}$ was recorded.

Table 2. Average seasonal values of selected physico-chemical indicators of studied waters

\begin{tabular}{|c|c|c|c|c|c|c|c|c|c|c|}
\hline & \multirow{2}{*}{ Parameter } & \multicolumn{3}{|c|}{ Lake Niepruszewskie } & \multicolumn{3}{|c|}{ Lake Pamiątkowskie } & \multicolumn{3}{|c|}{ Lake Strykowskie } \\
\hline & & spring & summer & autumn & spring & summer & autumn & spring & summer & autumn \\
\hline \multirow{3}{*}{$\mathrm{pH}$} & minimum & 7,80 & 7,60 & 7,50 & 7,80 & 7,50 & 7,60 & 7,90 & 7,82 & 7,60 \\
\hline & average & 8,22 & 8,13 & 8,07 & 8,24 & 8,14 & 8,08 & 8,43 & 8,33 & 8,05 \\
\hline & maximum & 8,65 & 8,79 & 8,62 & 8,65 & 8,85 & 8,67 & 9,25 & 9,19 & 8,61 \\
\hline \multirow{3}{*}{$\begin{array}{c}\mathrm{O}_{2} \\
{\left[\mathrm{mg} \cdot \mathrm{dm}^{-3}\right]}\end{array}$} & minimum & 4,80 & 4,80 & 4,80 & 4,80 & 5,60 & 6,40 & 5,60 & 5,47 & 5,47 \\
\hline & average & 9,11 & 7,39 & 7,81 & 9,33 & 7,58 & 8,34 & 10,22 & 8,72 & 7,68 \\
\hline & maximum & 12,80 & 10,60 & 10,80 & 15,60 & 10,40 & 10,80 & 16,67 & 11,47 & 8,67 \\
\hline \multirow{3}{*}{$\begin{array}{c}\mathrm{NO}_{3} \\
{\left[\mathrm{mg} \cdot \mathrm{dm}^{-3}\right]}\end{array}$} & minimum & 0,22 & 0,22 & $<$ LOD & 0,43 & 0,22 & $<$ LOD & $<$ LOD & $<$ LOD & $<$ LOD \\
\hline & average & 12,07 & 8,62 & 3,41 & 9,82 & 10,16 & 3,68 & 6,96 & 7,29 & 2,57 \\
\hline & maximum & 28,80 & 21,49 & 11,94 & 30,57 & 28,80 & 13,29 & 18,90 & 23,04 & 8,71 \\
\hline \multirow{3}{*}{$\begin{array}{c}\mathrm{NO}_{2} \\
{\left[\mathrm{mg} \cdot \mathrm{dm}^{-3}\right]}\end{array}$} & minimum & 0,07 & $<$ LOD & 0,01 & 0,03 & $<$ LOD & $<$ LOD & 0,03 & $<$ LOD & 0,02 \\
\hline & average & 0,16 & 0,06 & 0,05 & 0,14 & 0,03 & 0,04 & 0,12 & 0,03 & 0,06 \\
\hline & maximum & 0,28 & 0,21 & 0,10 & 0,36 & 0,10 & 0,10 & 0,42 & 0,07 & 0,13 \\
\hline \multirow{3}{*}{$\underset{\left[\mathrm{mg} \cdot \mathrm{dm}^{-3}\right]}{\mathrm{NH}_{4}}$} & minimum & $<\mathrm{LOD}$ & $<$ LOD & 0,01 & $<\mathrm{LOD}$ & $<$ LOD & $<$ LOD & $<$ LOD & $<$ LOD & 0,03 \\
\hline & average & 0,17 & 0,16 & 0,25 & 0,13 & 0,08 & 0,23 & 0,07 & 0,11 & 0,22 \\
\hline & maximum & 1,03 & 0,43 & 0,86 & 0,42 & 0,24 & 0,99 & 0,27 & 0,45 & 0,52 \\
\hline \multirow{4}{*}{$\begin{array}{l}\mathrm{N} \text { total. } \\
{\left[\mathrm{mg} \cdot \mathrm{dm}^{-3}\right]}\end{array}$} & minimum & 4,20 & 2,70 & 2,10 & 5,30 & 2,40 & 3,60 & 3,13 & 2,50 & 2,20 \\
\hline & average & 6,81 & 4,58 & 4,95 & 6,72 & 4,71 & 7,32 & 4,96 & 4,07 & 5,00 \\
\hline & maximum & 12,30 & 9,60 & 8,60 & 9,60 & 11,15 & 13,60 & 7,80 & 5,87 & 10,00 \\
\hline & the average of $2004-14$ & \multicolumn{3}{|c|}{5,41} & \multicolumn{3}{|c|}{6,31} & \multicolumn{3}{|c|}{4,70} \\
\hline \multirow{4}{*}{$\begin{array}{c}\mathrm{P} \text { total } \\
{\left[\mathrm{mg} \cdot \mathrm{dm}^{-3}\right]}\end{array}$} & minimum & 0,09 & 0,02 & 0,08 & 0,11 & 0,06 & 0,06 & 0,08 & 0,07 & 0,05 \\
\hline & average & 0,13 & 0,08 & 0,09 & 0,15 & 0,11 & 0,12 & 0,16 & 0,10 & 0,11 \\
\hline & maximum & 0,25 & 0,15 & 0,10 & 0,27 & 0,17 & 0,16 & 0,30 & 0,16 & 0,13 \\
\hline & the average of $2004-14$ & \multicolumn{3}{|c|}{0,10} & \multicolumn{3}{|c|}{0,13} & \multicolumn{3}{|c|}{0,12} \\
\hline \multirow{4}{*}{$\mathrm{N}: \mathrm{P}$} & minimum & 37,50 & 15,88 & 23,33 & 42,67 & 14,71 & 22,50 & 22,36 & 15,00 & 14,67 \\
\hline & average & 72,86 & 63,25 & 66,75 & 56,44 & 48,41 & 64,18 & 47,72 & 43,11 & 57,36 \\
\hline & maximum & 123,00 & 163,33 & 230,00 & 80,00 & 101,36 & 97,14 & 97,50 & 83,86 & 185,00 \\
\hline & the average of $2004-14$ & \multicolumn{3}{|c|}{67,22} & \multicolumn{3}{|c|}{56,86} & \multicolumn{3}{|c|}{50,04} \\
\hline
\end{tabular}




\section{Nitrates $\left(\mathrm{NO}_{3}\right)$}

The annual average concentration of nitrates in the waters was characterized by significant fluctuations in the period 2004-2014, but generally showed an upward trend until 2013 (Figure 1). Considering that agricultural activity is one of the main sources of nitrate pollution, it seems that actions to reduce runoff pollution from agricultural sources in areas classified as OSN in 2004 have not been very effective.

Throughout the 2004-2007 period the annual average concentration of $\mathrm{NO}_{3}$ in all the three lakes showed a similar level within the range of $0-4.87 \mathrm{mg} \mathrm{NO} \cdot \mathrm{dm}^{-3}$, which would correspond to waters of very good quality. The concentration reached the highest values in the spring season (3.98-7.97 $\left.\mathrm{mg} \mathrm{NO}_{3} \cdot \mathrm{dm}^{-3}\right)$. In 2008 a surge in nitrate concentrations was observed in all the studied lakes, especially during the spring and summer. Such a marked increase in nitrate concentrations in water could be due to intense precipitation in the months of January, March, April, July and August, which resulted in nitrate leaching from agricultural land. A study by Zbierska et al. (2011) conducted in the catchment of Lake Niepruszewskie showed that the ground water from fields does not supply nitrogen compounds to the lake. Analyses of surface waters in the area showed that watercourses were the main sources of biogens to the lake [Zbierska et al. 2002], which would also confirm a rapid increase in nitrate concentrations after heavy rainfall. After a significant drop in the concentration of nitrates in the years 2009 and 2010 it increased again. The highest concentrations were recorded in the spring season of 2012 (30.6 $\mathrm{mg} \mathrm{NO}_{3} \cdot \mathrm{dm}^{-3}$ in Lake Pamiątkowskie and $28.8 \mathrm{mg} \mathrm{NO}_{3} \cdot \mathrm{dm}^{-3}$ in Lake Niepruszewskie) and the summer of $2013\left(28.8 \mathrm{mg} \mathrm{NO}{ }_{3} \cdot \mathrm{dm}^{-3}\right.$ in Lake Pamiątkowskie). According to a study of 2014, the concentrations were lower and similar to those of 2011.

The highest mean nitrate concentrations in the waters of Lake Niepruszewskie were recorded in the spring (Table 2). Presumably this was related to spring fertilization of farmland and a lack of vegetation. The similar trends were found for maximum concentrations of nitrates. Only in Lake Strykowskie maximum concentrations of nitrates were recorded in the summer. In the spring and summer the concentrations of nitrates in the waters of studied lakes were quite similar and ranged on average at $6.96-12.07 \mathrm{mg}$ $\mathrm{NO}_{3} \cdot \mathrm{dm}^{-3}$. Significantly lower mean concentrations, at $2.57-3.68 \mathrm{mg} \mathrm{NO} \cdot \mathrm{dm}^{-3}$, were recorded in the autumn season. However, nitrate concentrations in the waters of all the lakes did not exceed the limit value $\left(50 \mathrm{mg} \mathrm{NO} \cdot \mathrm{dm}^{-3}\right)$ set out in the Nitrates Directive.

\section{Nitrate $\mathrm{NO}_{2}$}

Nitrate concentration was also characterized by relatively high variability in the years 2004-2014 and showed an upward trend in that

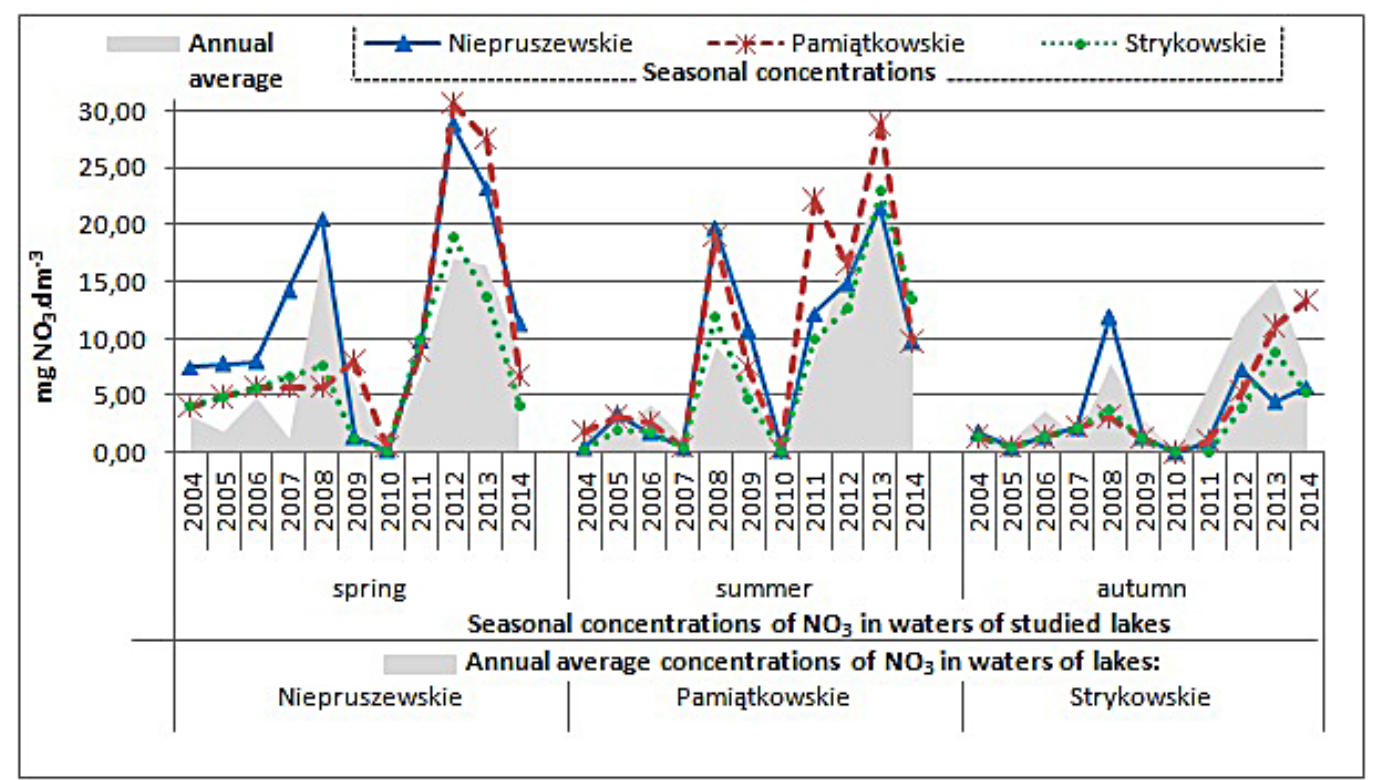

Figure 1. Seasonal and annual average concentrations of $\mathrm{NO}_{3}$ in waters of studied lakes in the hydrological years 2004-2014 


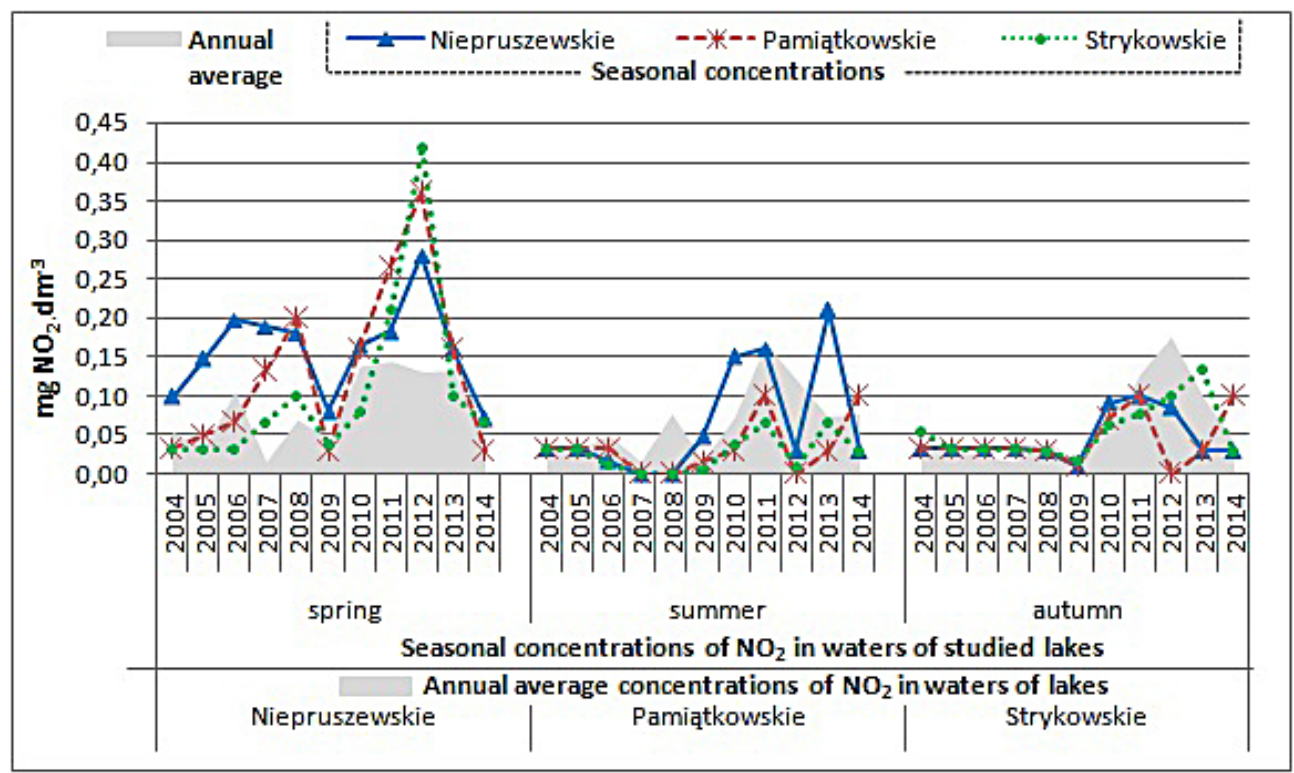

Figure 2. Seasonal and annual average concentrations of $\mathrm{NO}_{2}$ in waters of studied lakes in the hydrological years 2004-2014

decade (Figure 2). By 2009, nitrite concentration in waters of all studied lakes were generally lower than $0.1 \mathrm{mg} \mathrm{NO} \cdot \mathrm{dm}^{-3}$. In 2011 and 2012, nitrite concentrations were elevated in all the examined lakes throughout the growing season. Changes in the concentration of $\mathrm{NO}_{2}$ in the waters showed an evident seasonal variation as shown by the slightly parabolic shape of the curve. The lowest concentrations (an average of 0.03-0.06 $\mathrm{mg} \mathrm{NO} \cdot \mathrm{dm}^{-3}$ ) were recorded during the summer season, slightly higher in the autumn season, and more than two or three-fold concentrations in the spring season (Table 2).

\section{Ammonium $\mathrm{NH}_{4}$}

The mean annual concentration of ammonium in the waters of studied lakes was contained in the range of 0 to $1.03 \mathrm{mg} \mathrm{NH} \cdot \mathrm{dm}^{-3}$ only single rapid changes in the concentration of $\mathrm{NH}_{4}$. A marked downward trend in the concentrations of $\mathrm{NH}_{4}$ over the years 2004-2014, especially after 2007, shows a gradual improvement of wastewater management in areas surrounding the lakes (Figure 3).

In development strategies prepared in 2000-2004 for the communes of Buk, Dopiewo, Stęszew and Szamotuły, where the examined

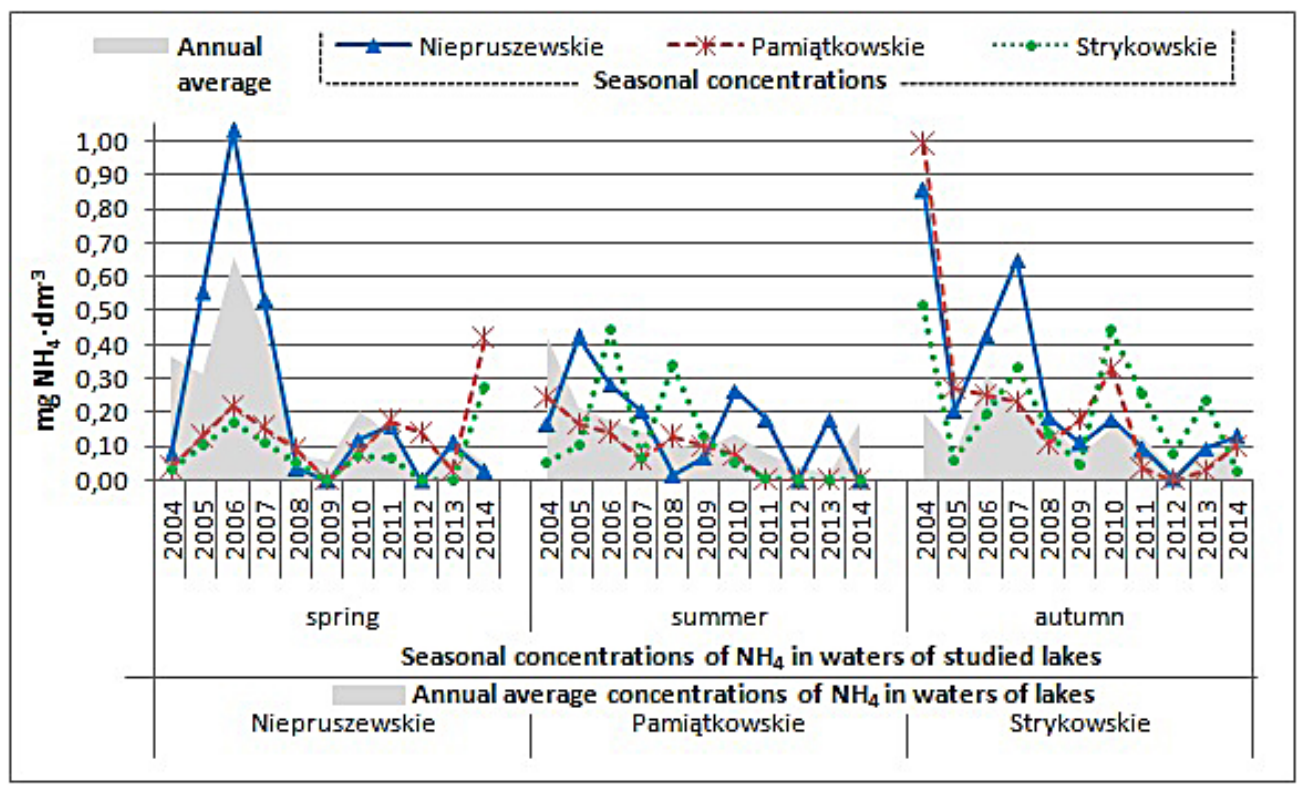

Figure 3. Seasonal and annual average concentrations of $\mathrm{NH}_{4}$ in waters of studied lakes in the hydrological years 2004-2014 
lakes are located, a lack of sewage systems in almost all the villages and the low standard of municipal wastewater treatment was defined as a priority issue that should be dealt with in the first place. In 2005-2008 a treatment plant in Pamiątkowo was modernised and in 2007-2014 a sanitary sewerage system was constructed for the villages of Przecław and Przecławek. In the Buk commune in 2008 a sewage treatment plant was constructed in the village of Niepruszewo, which was shown by a decrease in $\mathrm{NH}_{4}$ concentrations after that year. This positive trend was reinforced by the construction of the sewage system after 2012. In the Stęszew commune a sanitary sewage system for villages of Sapowice and Slupia, located at the northern and eastern shore of Lake Strykowskie, was completed in 2012 and 2013. A decrease in the concentrations of $\mathrm{NH}_{4}$ has been seen in the water of this lake since 2010.

Single sudden increase in the $\mathrm{NH}_{4}$ concentration recorded after these investments could be caused by the recreational use of the reservoirs in the summer and in the other seasons it could be due to works on the removal of septic tanks and testing of the sewerage system.

The concentrations of $\mathrm{NH}_{4}$ showed seasonal variations different than those of $\mathrm{NO}_{3}$ and $\mathrm{NO}_{2}$. The highest values were reported in the autumn season, while they were lowest in the summer season (Table 2). The autumn season is also characterized by the most variable $\mathrm{NH}_{4}$ concentration, especially in Lake Pamiątkowskie (from below the limit of quantification to $0.99 \mathrm{mg} \cdot \mathrm{dm}^{-3}$ ) and Lake Niepruszewskie $\left(0.01-0.86 \mathrm{mg} \cdot \mathrm{dm}^{-3}\right)$. For Lake Pamiątkowskie a gradual decrease was observed in $\mathrm{NH}_{4}$ concentration from $0.24 \mathrm{mg}$ $\mathrm{NH}_{4} \cdot \mathrm{dm}^{-3}$ to below the level of quantification. Analyses of the three lakes showed the highest values and changes of nitrites, nitrates and ammonia for Lake Niepruszewskie.

\section{Total nitrogen and total phosphorus}

Total nitrogen concentration reached the highest values in the autumn season. It ranged from $2.10 \mathrm{mg} \mathrm{N} \cdot \mathrm{dm}^{-3}$ (Lakes Niepruszewskie) to $13.60 \mathrm{mg} \mathrm{N} \cdot \mathrm{dm}^{-3}$ (Lake Pamiątkowskie) (Table 2). In 2011 a significant increase of total nitrogen concentrations in the water was observed - up to $6 \mathrm{mg} \mathrm{N} \cdot \mathrm{dm}^{-3}$ in Lake Strykowskie, to $8 \mathrm{mg} \mathrm{N} \cdot \mathrm{dm}^{-3}$ in Lake Niepruszewskie and up to $10 \mathrm{mg} \mathrm{N} \cdot \mathrm{dm}^{-3}$ in Lake Pamiątkowskie (Figure 4). This increase was observed in all seasons. This could be the result of leaching of nitrogen compounds by heavy rainfall in the autumn-winter period (XI-II 213 $\mathrm{mm})$ and in July $(185 \mathrm{~mm})$. In the other years mean annual concentrations were in the range of $4.0-6.0 \mathrm{mg} \mathrm{N} \cdot \mathrm{dm}^{-3}$. Concentrations of total nitrogen showed seasonal variations (Table 2). Higher nitrogen concentrations were recorded in spring and autumn, while they were lower in summer.

The concentration of total phosphorus in the lakes waters was generally low. In Lake Niepruszewskie throughout the period the mean annual concentration classified them to a good status, while in Lake Strykowskie they slightly exceeded the threshold for a good status in 2013 and 2014, and in Lake Pamiątkowskie in 2011-2014 (Table 3). The trends for seasonal variability are very similar to nitrogen concentrations in all the three lakes.

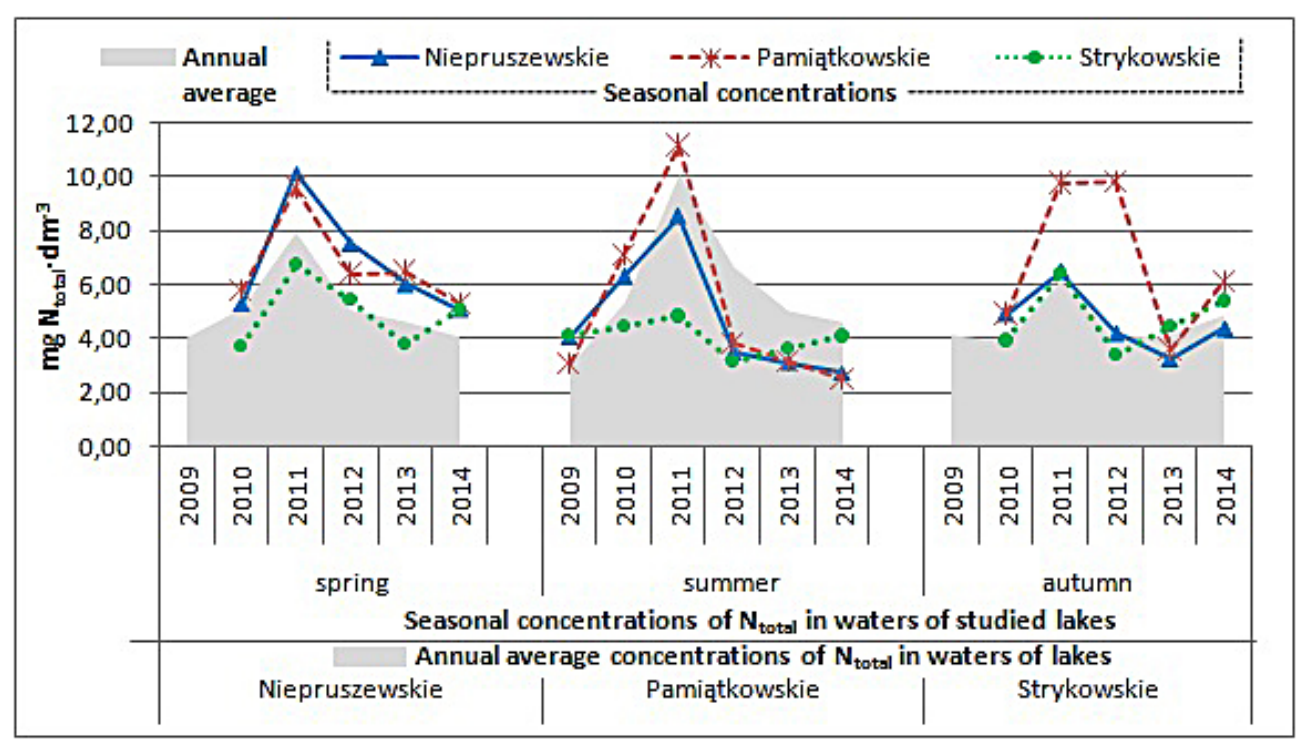

Figure 4. The annual average concentration of total nitrogen in the water studied lakes 
Slightly higher concentrations of phosphorus were recorded in the spring season, while they were lowest in summer (Table 2). In the spring we also observed a greater range of fluctuations in the concentration of this nutrient, which may have been the result of erosion during the spring thaw and before the onset of vegetation growth.

Referring the concentration of nitrogen and phosphorus to the criteria for the evaluation of the trophic status, they indicate advanced eutrophication of these waters. Nitrogen concentration in the waters of all the lakes in the entire study period corresponded to hypertrophy. The concentration of phosphorus in the waters of Lake Niepruszewskie in 2009-2013 corresponded to the eutrophic state, and in 2014 it increased to hypertrophy (Table 3). In Lake Pamiątkowskie the raise to the hypertrophy status was made already after 2011. In Lake Strykowskie the phosphorus level was the highest and in almost the entire period corresponded to hypertrophy, with the exception of 2010.

The ratio of the three basic elements: carbon, nitrogen and phosphorus, during photosynthe- sis is called the Redfield ratio [Redfield 1958] and it should amount to 106:16:1 [Hecky et al. 1993]. Deviations from this ratio indicate a biochemical imbalance and may indicate the limiting factors or stimulating the growth of aquatic organisms (productivity) [Zbierska et al. 2015]. Since carbon is very rarely present in excessive amounts, it is believed that nitrogen or phosphorus may be factors limiting productivity [Dojlido 1995]. The ratio of these two elements is also very important. The ratio of nitrogen $(\mathrm{N})$ to phosphorus $(\mathrm{P})$ concentrations in water analyzed since 2009, ranged from 30 in Lake Strykowskie (2013) to 135 in Lake Niepruszewskie (2010) (Table 3). This indicates that the lake has large surpluses of nitrogen and phosphorus is the main limiting factor of productivity. The ratio of $\mathrm{N}: \mathrm{P}$ shows less marked seasonal variations than are observed for its components (Figure 5). A lower concentration of nitrogen in the summer is also accompanied by reduced levels of phosphorus in the water. The greatest variation of this indicator is found in autumn.

Table 3. The average annual concentration of total nitrogen, total phosphorus and the ratio of N:P

\begin{tabular}{|c|c|c|c|c|c|c|}
\hline Lake & Year & $\mathrm{mg} \mathrm{N}_{\text {Total }} \cdot \mathrm{dm}^{-3}$ & Status ** & $\mathrm{mg} \mathrm{P}_{\text {Total }} \cdot \mathrm{dm}^{-3}$ & Status ** & Average $N: P$ \\
\hline \multirow{6}{*}{ 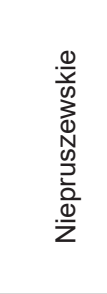 } & 2009 & 4.050 & $\mathrm{H}$ & 0.083 & E & 81 \\
\hline & 2010 & 4.900 & $\mathrm{H}$ & 0.075 & $E$ & 135 \\
\hline & 2011 & 7.913 & $\mathrm{H}$ & 0.095 & $E$ & 87 \\
\hline & 2012 & 5.067 & $\mathrm{H}$ & 0.095 & $\mathrm{E}$ & 53 \\
\hline & 2013 & 4.630 & $\mathrm{H}$ & 0.095 & $E$ & 48 \\
\hline & 2014 & 4.073 & $\mathrm{H}$ & 0.123 & $\mathrm{H}$ & 35 \\
\hline \multirow{6}{*}{ 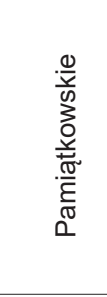 } & 2009 & 3.050 & $\mathrm{H}$ & 0.070 & $E$ & 50 \\
\hline & 2010 & 4.900 & $\mathrm{H}$ & 0.060 & $E$ & 82 \\
\hline & 2011 & 10.063 & $\mathrm{H}$ & 0.130 & $\mathrm{H}$ & 80 \\
\hline & 2012 & 6.667 & $\mathrm{H}$ & 0.137 & $\mathrm{H}$ & 52 \\
\hline & 2013 & 5.040 & $\mathrm{H}$ & 0.135 & $\mathrm{H}$ & 41 \\
\hline & 2014 & 4.630 & $\mathrm{H}$ & 0.133 & $\mathrm{H}$ & 38 \\
\hline \multirow{6}{*}{ 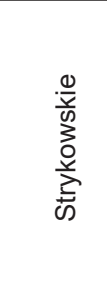 } & 2009 & 4.133 & $\mathrm{H}$ & 0.117 & $\mathrm{H}$ & 47 \\
\hline & 2010 & 3.933 & $\mathrm{H}$ & 0.053 & $E$ & 119 \\
\hline & 2011 & 6.099 & $\mathrm{H}$ & 0.101 & $\mathrm{H}$ & 66 \\
\hline & 2012 & 4.000 & $\mathrm{H}$ & 0.116 & $\mathrm{H}$ & 35 \\
\hline & 2013 & 4.137 & $\mathrm{H}$ & 0.140 & $\mathrm{H}$ & 30 \\
\hline & 2014 & 4.853 & $\mathrm{H}$ & 0.143 & $\mathrm{H}$ & 36 \\
\hline \multicolumn{2}{|l|}{ Acc. to: } & \multicolumn{5}{|c|}{ Limit values of eutrophication } \\
\hline \multicolumn{2}{|c|}{ Regulation* } & \multicolumn{2}{|c|}{$>1.5$} & \multicolumn{2}{|c|}{$>0.1$} & \\
\hline \multicolumn{2}{|c|}{ OECD [1982] } & \multicolumn{2}{|c|}{-} & \multicolumn{2}{|c|}{$\begin{array}{c}\text { E } 0.035-0.100 \\
H>0.100\end{array}$} & \\
\hline \multicolumn{2}{|c|}{ Nürnberg [2001] } & \multicolumn{2}{|c|}{$\begin{array}{c}E 0.650-1.200 \\
H>1.200\end{array}$} & \multicolumn{2}{|c|}{$\begin{array}{c}E 0.030-0.100 \\
H>0.100\end{array}$} & \\
\hline
\end{tabular}




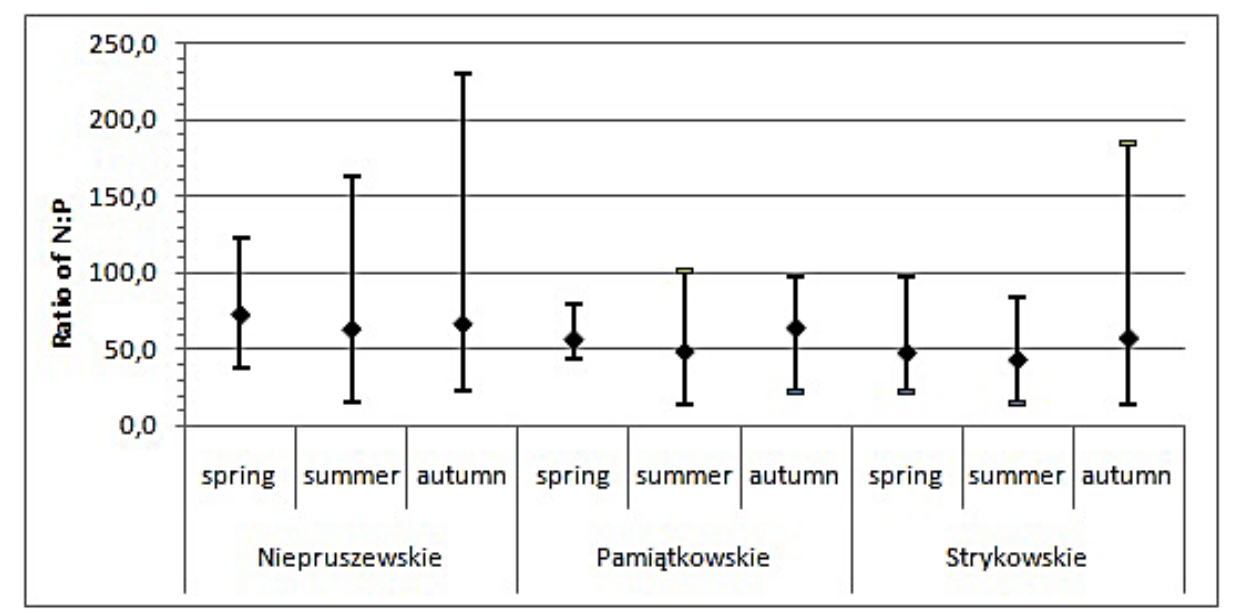

Figure 5. Seasonal variability of N:P ratio in the water of lakes in the period 2009-2014

High concentrations of biogens stimulate high productivity and contribute to trophic degradation. In the analyzed lakes an abundant growth of phytoplankton and macrophytes as well as dominance of cyprinids are observed. As a result in the current assessment of the ecological status of waters these lakes receive low scores. According to WIOŚ studies of 2010 waters of Lake Niepruszewskie were classified into Class II on the basis of biological indicators and according to the state of physical and chemical indicators below good status (decisive indicators were nitrogen and conductivity). Therefore, the general state of the lake is rated as moderate. Lake Pamiątkowskie according to WIOŚ studies of 2008 was considered eutrophic, which was confirmed by high levels of chlorophyll and the value of the macrophyte ESMI indicator. An overall assessment of Lake Strykowskie according to WIOŚ monitoring in 2010 showed the poor state of water, including biological indicators corresponding to class IV (chlorophyll and phytoplankton) and physicochemical indicators below good status (total nitrogen, conductivity and oxygen above the bottom). These analyses also confirmed eutrophication in the lake (chlorophyll, phytobenthos, nitrogen and phosphorus).

\section{CONCLUSIONS}

1. Studies have shown that the concentration of nutrients shows high variability both in individual years and seasons of the analyzed decades, especially in Lakes Niepruszewskie and Pamiątkowskie.
2. Concentrations of nitrates and nitrites in general showed an upward trend in the decade of 2004-2014, particularly in the spring. This may indicate that actions restricting runoff pollution from agricultural sources have not been very effective.

3. The concentration of ammonium in the analyzed period showed a downward trend, which may be the result of improved water and wastewater management in the catchments and reduced sewage discharge into the water.

4. The highest concentrations of nitrates and nitrites were recorded in the spring, while they were slightly lower in the summer and the lowest in the autumn season. The largest fluctuations were observed in Lakes Niepruszewskie and Pamiątkowskie. Fluctuations of nitrite levels were observed mainly in the spring, which may result from the release of nitrogen compounds from the decomposition of organic matter from lake sediments and the supply of nitrogen compounds from the catchment.

5. The concentrations of $\mathrm{NH}_{4}$ showed different seasonal variations than $\mathrm{NO}_{3}$ and $\mathrm{NO}_{2}$. The highest values were reported in the autumn season, and the lowest in the summer. In Lake Niepruszewskie large fluctuations in the concentrations of $\mathrm{NH}_{4}$ were recorded in the spring and autumn seasons, while in Lake Pamiątkowskie it was only in the autumn.

6. The high value of the N:P ratio (generally greater than 30) indicates that the lakes had huge surpluses of nitrogen, and phosphorus was a factor limiting productivity. 


\section{REFERENCES}

1. Bechmann M.E., Berge D., Eggestad H.O., Vandsemb S.M., 2005. Phosphorus transfer from agricultural areas and its impact on the eutrophication of lakes - two long-term integrated studies from Norway, J. Hydrol. 304, 1-4, 238-250.

2. Cherry K.A., Shepherd M., Withers P.J.A., Mooney S.J., 2008. Assessing the effectiveness of actions to mitigate nutrient loss from agriculture: a review of methods, Sci. Total Environ. 406, 1-23.

3. Choiński A., 2006. Katalog Jezior Polski, Wyd. Naukowe UAM, Poznań.

4. Czarnecka H., 2005. Atlas Podziału Hydrograficznego Polski Cz.1 i 2, Wyd. IMGW, Warszawa.

5. Directive 91/676/EEC of 12 December 1991 concerning the protection of waters against pollution caused by nitrates from agricultural sources (Nitrates Directive).

6. Dojlido J.R., 1995. Chemia wód powierzchniowych. Wydawnictwo Ekonomia i Środowisko, Warszawa.

7. Hecky R.E., Campell P., Hendzel L.L., 1993. The stoichiomentry of caron, nitorgen and phosphorus in particulate matter of lakes and oceans, Limnol. Oceanogr. 38 (4), 709-724.

8. Jańczak J., 1996. Atlas Jezior Polski, Tom I. IMGW, Poznań.

9. Kajak Z., 2001. Hydrobiologia-limnologia, Ekosystemy wód śródlądowych, Wyd. Nauk. PWN, Warszawa.

10. Ławniczak A.E., Zbierska J., Kupiec J., 2008. Changes of nutrient concentrations in water sensitive to nitrate pollution from agricultural sources in the Samica Stęszewska river catchment, Ann. Warsaw Univ. Life Sci. SGGW Land Reclam., 40, 15-25.

11. Murat-Błażejewska S., Zbierska J., Ławniczak A., Kanclerz J., Kupiec J., Sojka M., 2008. Eksploatacja urządzeń wodnych a zasoby wodne zlewni nizinnej, Acta Sci. Pol. Architectura 7 (2), 13-22.

12. Nurnberg G., 2001. Eutrophication and trophic state. Lake Line, 29(1), 29-33.

13. OECD Raport - Environmental Outlook to 2050. The Consequences of Inaction.

14. Przybyła C, Kozdrój P., Sojka M., 2014. Ocena jakości wód w lateralnych zbiornikach Jutrosin i Pakosław w pierwszych latach funkcjonowania. Inżynieria Ekologiczna, 39, 123-135.
15. Przybyła C., Zbierska A., Dwornikowska Ż., 2011. Ocena zmian jakości wody w wybranych jeziorach Pojezierza Poznańskiego w latach 2004-2009. Rocznik Ochrony Środowiska, 13, Koszalin, 723-746.

16. Redfield A.C., 1958. The biological control of chemical factors in the environment, Am. Sci. 46, 205-221.

17. Regulation of the Minister of Environment of 23 December 2002 (Dz.U. [Journal of Laws] 2002 No. 241 item. 2093] concerning the criteria for designation of waters vulnerable to pollution from nitrogen compounds from agricultural sources.

18. Regulation of the Minister of Environment of 22 October 2014 (Dz.U. [Journal of Laws] 2014 item 1482) concerning the classification of the status of surface waters.

19. UNESCO - The United Nations World Water Development Report 2014. Water and Energy, Paris 2014.

20. Vollenweider R.A., Kerekes J., 1982. Eutrophication of waters. Monitoring, assessment and control, OECD Cooperative programme on monitoring of inland waters (Eutrophication control), Environment Directorate, OECD, Paris.

21. WIOŚ - The Regional Inspectorate of Environmental Protection in Poznań, Raports from 2004, 2006, 2009, 2010, 2011. Wyd. Biblioteka Monitoringu Środowiska, Poznań.

22. Zbierska J., Ławniczak A., 2002. Zmiany zawartości składników nawozowych w wodach gruntowych strefy przybrzeżnej Jeziora Niepruszewskiego, Rocz. AR Pozn., Melior. Inż. Środ., 23.

23. Zbierska J., Ławniczak A.E., Kupiec J., Zbierska A., 2011. Stężenie składników biogennych w wodach gruntowych i podziemnych w zlewni bezpośredniej Jeziora Niepruszewskiego narażonego na zanieczyszczenia pochodzenia rolniczego, Nauka Przyr. Technol. 5(5), 103.

24. Zbierska J., Ławniczak A.E., Zbierska A., 2015. Changes in the trophic status of lake Niepruszewskie (Poland), Journal of Ecological Engineering, 16(4), 65-73.

25. Zbierska, J., Murat-Błażejewska, S., Szoszkiewicz, K., Ławniczak, A., 2002. Bilans biogenów w agroekosystemach Wielkopolski w aspekcie ochrony jakości wód na przykładzie zlewni Samicy Stęszewskiej, Wyd. AR Poznań. 